\title{
Acculturative issues of Muslims in Australia
}

\author{
Nigar G. Khawaja \& Sunnya Khawaja ${ }^{2}$ \\ School of Psychology \& Counselling ${ }^{1}$ \\ School of Public Health \& Social Work ${ }^{2}$ \\ Queensland University of Technology \\ Address Correspondence to: \\ Associate Professor Nigar Gohar Khawaja \\ Queensland University of Technology \\ Rm 525, O Block, B wing \\ Ring Road, \\ Kelvin Grove \\ Ph: +61412742946 \\ Email:n.khawaja@qut.edu.au
}

\section{Abstract}

Muslims in Australia are from a range of cultural and language groups. In spite of their long presence in Australia, research on this population is a recent development. The information that is emerging indicates that, in general, acculturation process is not problematic for the majority of Muslims. Most of them integrate well and report a blended identity. They value Australian institutions and contribute to the society in all spheres of life. However, acculturative stress has also emerged in the form of language barriers, employment challenges, financial disadvantages, and marginalization. These challenges have been associated with widespread negativity toward Muslims as a result of domestic and international terrorist attacks. Further, an adverse portrayal of Muslims in the media has contributed to the development of prejudices and Islamophobia among non-Muslim Australians, leading to discrimination and strained relations between the two groups. Although there is an ongoing attempt to repair relations between Muslims and the larger society in Australia, more effective strategies are required. Suggestions for stakeholders are discussed.

Keywords: Muslims, Australia, acculturation, acculturative stress 


\section{Acculturative issues of Muslims in Australia}

Australia is one of the most multicultural societies in the world. The Australian population comprises of people from 300 language and cultural groups (Australian Bureau of Statistics, 2013a). A number of ethnic groups, which contribute to that vast diversity, identify as Muslims. Muslims in Australia are in the minority, based both on religion and ethnic origins. Islam is the third most common religion in Australia (Pratt, 2011), and is the fastest growing religion in that country (Foster, Cook, Barter-Godfrey, \& Furneaux, 2011). Although Muslims have been living in Australia for centuries, the country has seen a rapid increase in the population of this group during the last three decades (Pratt, 2011). These Muslims, like all other immigrants, go through an adjustment and acculturation process. While their contributions were appreciated, since the $9 / 11$ terror attacks, they report having been perceived as a threat (Poynting \& Mason, 2006). Further, global terror activities and the negative portrayal of Muslims in the media have flared up anger and prejudices against them (Poynting \&Perry, 2007). These biases have at times strained the relations between the Muslims and the general population, and have made the acculturation process more challenging. In the following sections, studies with Muslims in Australia are reviewed with reference to their acculturation experiences. Suggestions that can be incorporated to facilitate their acculturation process are discussed. It is important to note that, to the authors' knowledge, acculturation and the acculturative stress have not yet been formally and systematically examined in Australia. Most of this information is inferred through other studies focussing on the experiences and challenges of Muslims in Australia.

\section{Origin, history and demographics of Muslims in Australia}

Historical records indicate that Muslims first sailed to the Australian continent in $17^{\text {th }}$ century (Saeed, 2004). There is also evidence of some Muslims entering Australia as settlers and convicts in as early as 1802 (Saeed, 2003). However, the first significant settlement of Muslims occurred in the 1860s, when Afghan cameleers and their families migrated to Australia (Yasmeen, 2010). Due to Australia's white-only policy ${ }^{1}$, very few Muslims entered Australia, and records of the few comprised of Afghan-and Malay-origin populations. A small number of Albanians arrived after World War I (Pratt, 2011). After World War

1. The 'White Australia' policy refers to legislation that restricted immigration of nonEuropean (non-white) people to Australia. The Immigration Restriction Act was enforced in 1901. The 'White Australia' policy was dismantled in 1966. https://www.border.gov.au/about/ corporate/information/fact-sheets/08abolition 
II, Muslims from Yugoslavia, Cyprus, Poland, Hungary, Russia, and Turkey migrated to Australia (Foroutan, 2008). The numbers increased slowly in the 1970s, once the white-only policy was eradicated and immigration from nonEuropean countries was permitted. The civil war in Lebanon in the late 1970s led to significant numbers of Lebanese migrants settling in Australia (Betts \& Healy, 2006). Similarly, a series of global crises and conflicts, including the Iran-Iraq War, turmoil in Afghanistan, the first Gulf War, civil war in Somalia, and growing militancy in Pakistan contributed to the increased presence of Muslims in Australia (Yasmeen, 2015).

In Australia, just over 2\% of the population identify themselves as Muslims (Australian Bureau of Statistics, 2013b). Of the entire Muslim population, $61.5 \%$ can be categorized as immigrants, born elsewhere and migrated to Australia. The remainder (39.5\%) are Australian-born, second-generation Muslims. The immigrant population represent 183 Middle Eastern, Asian, Eastern Europe, and African countries of origin (Hassan, 2010). The largest populations, in descending order, are from Lebanon, Turkey, Afghanistan, Bosnia/ Herzegovina, Pakistan, Indonesia, Iraq, Bangladesh, Iran, Fiji, Cypress, Somalia, Egypt, and Malaysia (Saeed, 2003, 2004). Nearly half of the Australian-born Muslims are from Lebanese and Turkish descent, and heritage of the others is linked with a wide range of countries (Yasmeen, 2015). Muslims are dispersed across all of the Australian states and territories, with the highest number settled in New South Wales and the second highest in Victoria (Hassan, 2015). The vast majority of Australian Muslims live in urban settings, with 75\% of them concentrating in Sydney and Melbourne (Hassan, 2015).

The Muslim population of Australia skews young: $77 \%$ are below the age of 44, with 37\% below the age of 24 (Peucker, Roose, \& Akbarzadeh, 2014). Being young, they are either in full-time education or working. Other biographical statistics reflect $80 \%$ of this population possesses a high proficiency of English (Hassan, 2015). Nearly 45\% have completed high school and the rest have tertiary education (Peucker et al., 2014). Muslim males, compared with the mainstream males, have a higher level of postgraduate qualification (Hassan, 2010). Muslims are in administration and services (32\%), blue collar (38\%), and professional and managerial (30\%) jobs (Hassan, 2015). Nine\% earn more than $\$ 3000$ per week, 38\% earn between $\$ 1250$ to $\$ 2999$ per week, $32 \%$ earn between $\$ 600$ - $\$ 1248$ per week, $18 \%$ earn $\$ 599$ or less per week and 3\% have no personal income (Hassan, 2015). The number of people who own a house is half of the national level (Hassan, 2010). Compared to 14\% of their countrymen, 27\% of Australian Muslim children live in poverty (Hassan, 2015). Elderly Muslims, when compared to average Australian seniors, have a higher rate of disability and require assistance for everyday life (Hassan, 2015). 


\section{Acculturation}

All those who immigrate to a new country undergo change, referred to as acculturation. It is an adaptation process where different ethnic groups meet and interact and subsequently change by adopting others' beliefs, values, norms, outlooks, traditions, customs, and behaviors (Sam \& Berry, 2010). Though it is a two-way process in theory, in reality the minority has to embrace the ways of the larger majority (Berry, 2005). Changes occur at the psychological and sociocultural level (Ward, 2008); Individuals from minority backgrounds can either marginalize and isolate, or assimilate and integrate into the dominant culture (Berry \& Sam, 2012). Integration, which is an amalgamation of original and adopted cultures and belief systems, is regarded as the favorable outcome. However, integration is affected by the ideas and perspective of the newly arrived as well as the expectations, attitudes, and behaviors of the host society. It is important for the members of the larger society to accept and engage with its minorities (Bourhis, Moise, Perreault, \& Senecal, 1997). Overall, acculturation is a complex multidimensional phenomenon, with changes occurring at numerous levels.

A review of the literature indicated limited information about the acculturation, adaptation, and integration of Muslims in Australia (Fozdar, 2011). To address this gap, researchers have recently started to focus on their settlement process, experiences, and challenges encountered. The information that is available indicates that, in the past, Muslim immigrants settled well, lived peacefully, valued their host society, and contributed to Australia's economic development (Pratt, 2011). They valued the significance of developing English proficiency (Sheppard, 2015) and respected Australian democratic and judicial systems (Rane, Nathie, Isakhan, \& Abdalla, 2011). Additionally, Rane and colleagues (2011) identified Australian Muslim appreciation for the educational and health care systems in Australia. Surveys on Muslims in Australia have highlighted that majority of them are not "radicalized" (Kabir, 2008a) and are loyal to their adopted country (Yucel, 2015). Further, investigations on the values of the Muslims in Australia indicated that participants perceived their values to be aligned with universal moral and ethical values (Kabir, 2008a). Allegiance to Australia has become evident through a 2015 report based on the most recent (2011) census data, according to which $74 \%$ of respondents identified themselves as Australian (Hassan, 2015). Studies exploring identity issues found that Australian Muslims reported feeling that they can be good Muslims and good Australians (Woodlock, 2011); further, the majority of the respondents reported a bicultural identity (Kabir, 2011; Woodlock, 2011). Muslim immigrants to Australia like to adapt, but also want to retain their original culture, language, and religious identity (Poynting, 2009). Pratt (2011) 
described Australian Muslims as using their value system and bicultural identity to uplift the status of their communities; this was indicated by the community's establishment of institutions: a large number of restaurants and businesses, approximately 100 mosques, and 30 Islamic schools across the country (Pratt, 2011). As yet, there is inadequate information about Muslim engagement with mainstream Australian; however, the data emerging indicated that most of the skilled Muslim population interacted with members of the larger society (Fozdar, 2011). Studies examining the psychological factors identify varying levels of self esteem (Every \& Perry, 2014). When assessed at the individual level, reports of wellbeing appeared to be similar to that of non-immigrant Australians; at the national level, however, it appeared to be lower than Australians (though still within average range; Woodlock, 2012). Acculturation is not an easy process and can precipitate psychosocial challenges for minorities and the larger majority.

\section{Acculturative Stress}

Psychosocial and cultural challenges experienced by the immigrant community resulting from the acculturation process are referred to as "acculturative stress" (Sam \& Berry, 2010). Studies conducted in Australia reveal that Muslims have experienced acculturative stress. Acquisition of the English language has been a difficult task, leading to language barriers and a sense of isolation and psychological distress (Casimiro, Hancock, \& Northcote, 2007; Khawaja, 2007). Some children of immigrants report feeling torn between their parents' world and their peers' world (Poynting, 2009), and describe integrating the two cultures as stressful. Securing employment has been a major difficulty due to discrimination (Casimiro et al., 2007). There is evidence that, when compared to mainstream applicants, Australian Muslims encounter severe problems securing jobs, and very often do not even get interviews (Centre for Muslim Minorities \& Islam Policy Studies, 2009). Peucker and colleagues (2014) report similar findings. Subsequently, unemployment has aggravated poverty (Hassan, 2015). Socioeconomic marginalization and a sense of deprivation are hypothesized as salient factors associated with religious and non-religious "radicalization" (Hassan, 2010). Youth, a period of unemployment, is postulated to be more vulnerable and at risk due to being in a physical and emotional developmental stage (Hassan, 2015). Muslims have emerged as a disadvantaged section of the Australian population (Peucker et al., 2014).

Investigations are indicating that Muslims in Australia tend to feel less safe (Centre for Muslim Minorities, 2009) and worry about their future safety and security (Woodlock, 2012). There in an overwhelming concern regarding the media, as it is not viewed as trustworthy (Rane \& Hersi, 2012). There 
has been a large number of negative stories about Muslims in the media since 2000; This is a consequence of tragic events, such as a gang rape of woman in Sydney by Muslim men, insensitive comments by someone claiming to be a Muslim leader, and the Cronulla riots (Bouma, 2011; Dunn, Klocher, \& Salabey, 2007); media reports on Muslims have similarly worsened after international and national terror attacks. Muslims report being frustrated with the attention on the behavior of an infinitesimal percentage of Muslims (Poynting \& Perry, 2007). Media reporting, which is perceived by Muslims as one-sided (Kabir, 2008b), has presented them as illiterate and ill-informed traitors and sympathizers of terrorists (HREOC, 2004; Poynting \& Mason, 2006). There is a general impression that Muslim do not assimilate in with the majority (Fozdar, 2011). This notion has been reinforced by politicians, some of whom have used a narrow definition of integration based on cultural indicators (attire worn, language used, and food consumed) instead of the broader financial, political, and social indicators (contributing to society through paid and unpaid work, and social interaction with the majority). Some media reports have represented hijab and niqab in an inaccurate and biased manner (Hebbani \& Wills, 2012; Kabir, 2006). Subsequently, Muslim women, particularly those who wore hijab and niqab, report encountering more prejudicial treatment (Yasmeen, 2007). Suspicion has increased toward those who appear to be from the Muslim world (Foster et al., 2011); consequently these individuals have been at a higher disadvantage (Dellal, 2004). Australian governments, past and present, have tried to curb terrorism through their "war on terror" campaign. This approach has led to surveillance, interrogation, and mandating Muslim leaders and schools to teach "Australian" values (Pratt, 2011; Spalek \& Imtoual, 2007). These efforts have been perceived as an intrusion by the state into the religious and cultural affairs of Muslim citizens (Poynting \& Mason, 2008) and have increased stress upon them (Michael, 2009). Muslims are more likely to be stopped and searched for security reasons, and more likely to be tried in the courts (Poynting \& Perry, 2007). Consequently, media and governmental policies have contributed to the rising rates of Islamophobia, which is present in the form of unfounded fears, and prejudicial and stereotypical thinking (Bouma, 2011; Dunn et al., 2007; Ho, 2007; Kabir, 2007). There is an element of "us versus them" thinking on the behalf of non-Muslim Australians, which is tarnishing the social inclusivity and harmony in Australia (Ata, 2015; Hopkins, 2011; Poynting \& Mason, 2006). Contrary to the "war on terror" strategy, a softer approach is also being tried, which is more socially inclusive, involves community engagement, and is perceived more favorably by Australian Muslims as they appreciate being actively involved in the safety and wellbeing of their adopted country (Spalek \& Imtoual, 2007). 


\section{Implications}

The outcome of the studies conducted on Muslims in Australia is mixed and inconclusive. Muslims appear to be well-adjusted, and appreciative of their host society and optimistic about their lives (Pratt, 2011). Nevertheless, there is an indication of acculturative stress. The psychosocial and financial challenges appear to be associated with the prejudices and discriminations in Australia (Centre for Muslim Minorities, 2009; Casimiro et al., 2007; Khawaja, 2007). The negative representation of Muslims has exacerbated Islamophobia, leading to strained relations between Muslim and non-Muslim Australians (Hopkins, 2011; Poynting \& Mason, 2006). Acculturation is a multifaceted issue, therefore, to acculturate and integrate well into the society, there are multiple factors that need to be taken into consideration by the Muslims (Bourhis et al., 1997). Firstly, they need to play an active role in their process of acculturation by continuing to learn the English language and acquire relevant knowledge and skills for successful adaptation into Australian society. Muslim immigrants need to draw on their resilience and personal and collective strengths to manage the stressors associated with migration to a new country and with being a minority. Due to the negative portrayal of Muslims through media and heightened level of terror, it may be difficult for non-Muslim Australians to completely trust their Muslim neighbors. It is therefore vital for Muslims to continue engaging with the larger majority in order to offer insights on themselves and their religion. Interactions like this will diffuse misconceptions and misunderstandings about Islam and address stereotypes about Muslims. To regain the lost trust, Muslims need to inform the public that extremism and terrorist activity has no place in Islam and these negative actions should not be generalized to all Muslims. Moreover, the Australian perspective and definition of 'integration' needs revision and modification. Integration, in multicultural Australian society, should not be restricted to speaking fluent English, wearing western clothing, and consuming local food; rather, it should be measured by a person's social harmony and contribution to the wider society. Further, stakeholders including politicians need to ensure that policies are inclusive and accepting. The "war on terror" campaign can be equitable, fair, and socially inclusive. The media has to play a more ethical role by presenting facts only, with context, and avoid divisive rhetoric. Finally, stakeholders need to pay urgent attention to Muslims who are socially disadvantaged, through unemployment, poverty, and marginalization. It is critical to assist these individuals in order to prevent them from being susceptible to criminal temptations, radicalization, or serious mental health issues. Youth, who are often more vulnerable due to the developmental stage and emotional immaturity, require the most immediate attention. 


\section{Limitations and Future Directions}

Research with the Australian Muslim population is limited. Investigations have increased only in the last two decades, once Muslims became visible due internal social issues and terrorist attacks. Most of the studies conducted are qualitative or based on small quantitative data sets. Though this is a helpful first step, extensive mixed-method investigations with large samples that represent Australian Muslims nationally are warranted. Although, past research has extensively explored the impact of the media and Islamophobia, there has been a dearth of studies examining the acculturation process, acculturative stress, and other mental health issues. There is a need for the future studies to examine these psychosocial aspects of adaptation.

\section{Conclusion}

A review of the literature indicates that while a majority of Australian Muslim immigrants acculturate and adjust adequately, a minority appears to struggle. Moreover, a few outliers have damaged the reputation of Muslim community with their criminal and terror-related activities. The disproportionate attention paid by the media to the disreputable activities of a handful of people has polarized Australian society and intensified Islamophobia. All these developments have hindered the adjustment of Muslims and stained their relationship with the larger society. Muslim immigrants and broader society have to work together to address these problems.

\section{References}

Ata, A. (2015). How Muslim students' knowledge of Christianity is related to their attitudes to mainstream Australia and Australians: A national survey. Social Sciences, 4(3), 800-805. doi:10.3390/socsci4030800

Australian Bureau of Statistics. (2013a). Australian social trends. Retrieved on 24 December, 2015 from http://www.abs.gov.au/AUSSTATS/abs@.nsf/Lookup/4102.0M ain + Features30April +2013

Australian Bureau of Statistics. (2013b). Reflecting a nation: Stories from the 2011 census, 2012- 2013. Retrieved on 24 December, 2015 from http://www.abs.gov.au/ ausstats/abs@.nsf/Lookup/2071.0main+features902012-2013

Berry, J. W. (2005). Acculturation: Living successfully in two cultures. International Journal of Intercultural Relations, 29, 697-712. https://doi.org/10.1016/j.ijintrel.2005.07.013

Berry, J. W., \& Sam, D. (2012). Multicultural societies. In V. Benet-Martínez \& Y-Y. Hong (Eds.), Handbook of multicultural identity: Basic and applied perspectives. New York: Oxford University Press. 
Betts, K., \& Healy, H. (2006). Lebanese Muslims in Australia and social disadvantage. People and Place, 14(1), 24- 42.

Bouma, G. D. (2011). Islamophobia as a constraint to world peace: The case of Australia. Islam and Christian-Muslim Relations, 22, 433-441. doi:10.1080/09596410.2 011.606189

Bourhis, R. Y., Moise, L. C., Perreault, S., Senecal, S. (1997). Towards an Interactive Acculturation Model: A social psychological approach. International Journal of Psychology, 32, 369-386. https://doi.org/10.1080/002075997400629

Casimiro, S., Hancock, P., \& Northcote, J. (2007). Isolation and insecurity: Resettlement issues among Muslim refugee women in Perth, Western Australia. Australian Journal of Social Issues, 42(1), 55-69.

Centre for Muslim Minorities \& Islam Policy Studies. (2009). Mapping employment and education among Australian Muslims. Monash, VIC: Australian Department of Immigration and Citizenship. Retrieved on 24 December, 2015 from: https:// www.dss.gov.au/sites/default/files/documents/01_2014/muslim-mapping-report. pdf

Dellal, H. (2004). Of 'middle eastern appearance': Police and Muslim communities in Australia. Around the Globe,1(3), 14-17.

Dunn, K. M., Klocker, N., \& Salabay, T. (2007). Contemporary racism and Islamaphobia [sic] in Australia: Racializing religion. Ethnicities, 7(4), 564-589. doi:10.1177/1468796807084017

Every, D., \& Perry, R. (2014). The relationship between perceived religious discrimination and self-esteem for Muslim Australians. Australian Journal of Psychology, 66(4), 241-248. doi:10.1111/ajpy.12067

Foroutan, Y. (2008). Employment differentials of second-generation Muslim Immigrants: Assimilation and discrimination hypotheses. Immigrants \& Minorities, 26(3), 219-241. doi:10.1080/02619280802528452

Foster, N., Cook, K., Barter-Godfrey, S., \& Furneaux, S. (2011). Fractured multiculturalism: Conflicting representations of Arab and Muslim Australians in Australian print media. Media, Culture \& Society, 33, 619-629. doi:10.1177/0163443711399034

Fozdar, F. (2011). Social cohesion and skilled Muslim refugees in Australia: Employment, social capital and discrimination. Journal of Sociology, 48(2), 167-186. doi:10.1177/1440783311413482

Hassan, R. (2010). Socio-economic marginalization of Muslims in contemporary Australia: Implications for social inclusion. Journal of Muslim Minority Affairs, 30(4), 575-584. doi:10.1080/13602004.2010.533455

Hassan, R. (2015). Australian Muslims. A demographic, social and economic profile of Muslims in Austalia. Retreived on 24 Dec 2015 from https://www.unisa.edu.au/ Global/EASS/MnM/Publications/Australian_Muslims_Report_2015.pdf

Hebbani, A., \& Wills, C. (2012). How Muslim women in Australia navigate through media (mis)representations of hijab/burqa. Australian Journal of Communication, 39(1), 87-100.

Ho, C. (2007). Muslim women's new defenders: Women's rights, nationalism and Islamophobia in contemporary Australia. Women's Studies International Forum, 30(4), 290-298. doi:10.1016/j.wsif.2007.05.002

Hopkins, L. (2011). A contested identity: Resisting the category Muslim-Australian. Immigrants \& Minorities, 29(1), 110-131. doi:10.1080/02619288.2011.553139

HREOC (Human Rights and Equal Opportunities Commission) (2004) 'Experiences of discrimination, vilification and prejudice', in HREOC, Isma - Listen. Retreived 
on 24 Dec 2015 from: http://www.hreoc.gov.au/racial_discrimination/isma/index. html.

Kabir, N. (2006). Muslims in a 'White Australia': Colour or religion? Immigrants \& Minorities, 24(2), 193-223. doi:10.1080/02619280600863671

Kabir, N. (2007). Muslims in Australia: The double edge of terrorism. Journal of Ethnic and Migration Studies, 33(8), 1277-1297. doi:10.1080/13691830701614072

Kabir, N. A. (2008a). Are young Muslims adopting Australian values? Australian Journal of Education, 52(3), 229-241. doi:10.1177/000494410805200302

Kabir, N. A. (2008b). "the media Is one-sided in Australia". Journal of Children and Media, 2(3), 267-281. doi:10.1080/17482790802327566

Kabir, N. A. (2011). A study of Australian Muslim youth identity: The Melbourne Case. Journal of Muslim Minority Affairs, 31(2), 243-258. doi:10.1080/13602004.2011. 583518

Khawaja, N.G (2007). An investigation of the psychologacl distess of Muslim migrants in Australia. Journal of Muslim Mental Health, 2:39-56. doi: $10.1080 / 15564900701238526$

Michael, M. S. (2009). Australia's handling of tensions between Islam and the West under the Howard government. Asian Journal of Political Science, 17(1), 45-70. doi:10.1080/02185370902767599

Peucker, M., Roose, J. M., \& Akbarzadeh, S. (2014). Muslim active citizenship in Australia: Socioeconomic challenges and the emergence of a Muslim elite. Australian Journal of Political Science, 49(2), 282-299. doi:10.1080/10361146.2014.899967

Poynting, S. (2009). The 'lost' girls: Muslim young women in Australia. Journal of Intercultural Studies, 30(4), 373-386. doi:10.1080/07256860903214123

Poynting, S., \& Mason, V. (2006). “Tolerance, freedom, justice and peace”?: Britain, Australia and Anti-Muslim Racism since 11 September 2001. Journal of Intercultural Studies, 27(4), 365-391. doi:10.1080/07256860600934973

Poynting, S., \& Mason, V. (2008). The new integrationism, the state and Islamophobia: Retreat from multiculturalism in Australia. International Journal of Law, Crime and Justice, 36(4), 230-246. doi:10.1016/j.ijlcj.2008.08.001

Poynting, S., \& Perry, B. (2007). Climates of hate: Media and state inspired victimisation of Muslims in Canada and Australia since 9/11. Current Issues in Criminal Justice, 19(2), 151-171.

Pratt, D. (2011). Antipodean ummah: Islam and Muslims in Australia and New Zealand. Religion Compass, 5(12), 743-752. doi:10.1111/j.1749-8171.2011.00322.x

Rane, H., \& Hersi, A. (2012). Meanings of integration in the Australian press coverage of Muslims: Implications for social inclusion and exclusion. Media International Australia, Incorporating Culture \& Policy, (142), 135-147.

Rane, H., Nathie, M., Isakhan, B., \& Abdalla, M. (2011). Towards understanding what Australia's Muslims really think. Journal of Sociology, 47(2), 123-143. doi: $10.1177 / 1440783310386829$

Saeed, A. (2003) Islam in Australia. Crows Nest, NSW: Allen and Unwin.

Saeed, A. (2004). Muslim Australians: Their beliefs, practices and institutions. Melbourne: Department of Immigration and Multicultural and Indigenous Affairs.

Sam, D. L., and Berry, J. W. (2010). Acculturation: When individuals and groups of cultural backgrounds meet. Perspectives on Psychological Science, 5(4) 472-481. https://doi.org/10.1177/1745691610373075

Sheppard, J. (2015) Australian attitudes towards national identity: citizenship, immi- 
gration and tradition, Report no. 18, ANU College of Arts and Social Sciences, Australian National University, Canberra.

Spalek, B., \& Imtoual, A. (2007). Muslim communities and counter-terror responses: "hard" approaches to community engagement in the UK and Australia. Journal of Muslim Minority Affairs, 27(2), 185-202. doi:10.1080/13602000701536117

Ward, C. (2008). Thinking outside the Berry boxes: new perspectives on identity, acculturation and intercultural relations. International Journal of Intercultural Relations, 32, 114-123. https://doi.org/10.1016/j.ijintrel.2007.11.002

Woodlock, R. (2011). Being an Aussie Mossie: Muslim and Australian identity among Australian-born Muslims. Islam and Christian-Muslim Relations, 22(4), 391-407. doi:10.1080/09596410.2011.606187

Woodlock, R. (2012). Muslim wellbeing in Australia: an analysis of personal and national wellbeing among a sample of Muslims living in New South Wales and Victoria. Islam and Christian-Muslim Relations, 23(2), 181-200. doi:10.1080/09596 410.2012.655063

Yasmeen, S. (2007). Muslim women as citizens in Australia: Diverse notions and practices. Australian Journal of Social Issues, the, 42(1), 41-54.

Yasmeen, S. (ed.) (2010) Muslims in Australia: The Dynamics of Exclusion and Inclusion Melbourne: Melbourne University Press.

Yasmeen, S.2015, 'Muslim in Australia: Celebrating national days'. Contemporary Review of the Middle East, 2, 1 \& 2,104-118. https://doi.org/10.1177/2347798915577720

Yucel, S. (2015) Do Muslims see Australia as their Homeland? The notion of watan al-asli and watan al-sukna in Islam, Journal of Muslim Minority Affairs, 35, 2, 191202.doi: 10.1080/13602004.2015.1039813 
